\title{
PENGARUH MASSA FILLER- MATRIKS TERHADAP SIFAT MEKANIK DAN DAYA SERAP AIR PADA KOMPOSIT CANGKANG BIJI KARET
}

\section{Andi Idhil Ismail}

Dosen

Institut Teknologi Kalimantan Program

Studi Teknik Mesin

a.idhil@lecturer.itk.ac.id

Rasidah

Mahasiswa

Mahasiswa S1 Institut Teknologi Kalimantan Program Studi Teknik Mesin 03161060@student.itk.ac.id

Ridhwan Haliq

Dosen

Institut Teknologi Kalimantan Program

Studi Teknik Mesin ridhwanhaliq@lecturer.itk.ac.id
The amount of rubber seed waste in Indonesia is highly yielded as a side product from a large amount of rubber trees plantation. The rubber seed was not processed become the usefull application yet, thus it becomes a high volume of waste in each year. An initiative should be done to turn it as a practical material. The rubber seed is potential for natural composite along with the increasing attention toward natural composite application.This work aims to produce natural fibre composite based on rubber seed and characterize it's mechanical properties. In this work, the rubber seed natural composite produced by using the hand lay-up method. Polyester resin YUCALAC BQTN-157 was used as the matrix with the addition of 1\% MEKP (Methyl-Ethyl-Ketone-Peroxide) as the catalyst. Mechanical properties of the composite were examined by using a tensile and bending test. Additionally, the water absorption test was performed according to the ASTM D 570. The result showed that the tensile and bending strength decrease with increasing the filler composition, which is added in the composite. The composite, which has the filler composition of $40 \%$ was generate the highest tensile strength. In contrast, the lowest tensile strength appeared at the composite with a filler of $60 \%$. The bending strength trend also behaves similarly with the tensile strength as the filler composition increased. Water absorption ability of composites displays the acceptable value as it shows within the range of $2.22-2.96 \%$.

Keywords: Composite; Filler; Hand Lay-Up Method; Rubber Seed Shell.

\section{PENDAHULUAN}

Tingginya permintaan furnitur dan bahan bangunan menyebabkan meningkatnya penebangan kayu yang secara langsung berakibat buruk dalam beberapa aspek, seperti kesuburan tanah berkurang, sumber daya air turun, keanekaragaman hayati hilang, serta terjadinya banjir dan tanah longsor yang semakin sering timbul di Indonesia. Selain itu, stabilitas lingkungan mulai tidak terjaga akibat siklus pertumbuhan kayu sangat lambat, yaitu bisa mencapai 10 tahun. Hal tersebut berdampak pada harga kayu di pasaran yang semakin tinggi. Upaya pengurangan penggunaan kayu sebagai bahan dasar furnitur dan bangunan terus dilakukan misalnya penggunaan logam ringan, dan plastik. Selain itu, komposit juga menjadi bahan alternatif yang banyak dikaji untuk aplikasi furnitur dan bahan bangunan. Perkembangan sains dan teknologi saat ini mampu mendorong pengaplikasian material komposit diberbagai produk. Umumnya bahan yang digunakan pada pembuatan komposit adalah material yang susah terurai kembali seperti serat kaca dan serat karbon, untuk itu diperlukan pengembangan di bidang material komposit jenis serat alam agar tidak menimbulkan dampak buruk bagi lingkungan. Provinsi Kalimantan Timur mempunyai potensi yang besar pada sektor perkebunan dan pertanian. Salah satu jenis perkebunan yang potensial untuk tumbuh adalah pohon karet (Hevea brasilience). Menurut data statistik dinas perkebunan Provinsi Kalimantan Timur, luas areal perkebunan karet tahun 2018 tercatat 
seluas 115.082 Ha yang terdiri dari areal perkebunan rakyat seluas 92.354 Ha [1].

Karet termasuk dalam divisi: spermatophyte, subdivisi angiospermae dan dalam kelas dicotyledonae, ordo euphorbiales, family euphorbiance, genus hevea, serta termasuk spesies Hevea brasiliensis. Sebagai penghasil serta alam, tanaman karet banyak dibudidayakan dengan menggores bagian batang tanaman untuk mendapatkan bahan karet alam yang bernilai ekonomis. Selain serat alam tanaman karet juga menghasilkan biji karet yang berbentuk ellipsoidal seperti pada Gambar 1a. Potensi cangkang biji karet yang dihasilkan yaitu sebesar $500 \mathrm{Kg} / \mathrm{tahun}$. Apabila luas areal perkebunan karet mencapai $115.082 \mathrm{Ha}$, maka limbah cangkang biji karet yang dihasilkan sekitar 57.541 ton/tahun. Cangkang biji karet hingga saat ini, masih belum dimanfaatkan melainkan hanya menjadi limbah perkebunan. Secara fisik cangkang biji karet memiliki ciri konstruksi cangkang yang keras yang mengindikasikan bahwa cangkang biji karet ini mengandung senyawa berupa lignoselulosa [2]. Bahan yang memiliki senyawa lignoselulosa telah banyak dikembangkan menjadi produk komposit sebagai filler yaitu cangkang kelapa, kulit kacang tanah, ampas padi, dan lain-lain. Salah satu inovasi sebagai alternatif baru yaitu penggunaan cangkang biji karet yang dihaluskan menjadi serbuk sehingga menjadi bahan filler dalam pembuatan komposit. Penggunaan serat alam atau bahan pengisi bersumber dari alam menjadi makin populer dan menarik perhatian ilmuwan untuk mengkaji secara luas baik itu dari sisi metode produksi, karakterisasi sifat-sifat kimia, mekanik, dan fisika sampai kepada kajian implementasi komposit serat alam dalam berbagai industri.

Memunculkan selulosa dan menghilangkan pengotor pada serat alam dilakukan dengan menggunakan metode alkalisasi. Alkalisasi digunakan untuk menghilangkan lapisan lignin pada permukaan serat alam dalam penelitian ini digunakan cangkang biji karet, proses dilakukan dengan merendam serat alam pada larutan alkali $(\mathrm{NaOH})$ dengan perlakuan temperatur dan waktu tertentu, waktu alkalisasi yang baik dilakukan selama dua hingga tiga jam perendaman [3]. Proses alkalisasi akan terjadi peristiwa lignin bereaksi dengan larutan $\mathrm{NaOH}$ yang terdisosiasi menjadi $\mathrm{Na}^{+}$dan $\mathrm{OH}^{-}$, ion $\mathrm{OH}^{-}$bereaksi dengan gugus $\mathrm{H}$ pada lignin, kemudian membentuk $\mathrm{H}_{2} \mathrm{O}$. Hal tersebut mengakibatkan gugus $\mathrm{O}$ membentuk radikal bebas dan reaktif dengan $\mathrm{C}$ kemudian membentuk cincin epoksi (C-O-C), lalu serangkaian gugus melepaskan ikatan pada gugus $\mathrm{O}$ dan menghasilkan dua cincin benzene dimana masing- masing cincin memiliki gugus $\mathrm{O}$ yang reaktif. Gugus $\mathrm{O}$ yang reaktif ini akan bereaksi dengan $\mathrm{Na}+$ dan ikut larut dalam air aquades atau air destilasi, sehingga lignin hilang ketika serat alam dibilas [4].

Ketersediaan bahan cangkang biji karet yang melimpah dan usaha untuk memberikan nilai tambah pada tanaman karet menjadi motivasi untuk eksplorasi pemanfaatan yang lebih baik. Penelitian ini bertujuan untuk memanfaatkan limbah cangkang biji karet sebagai bahan filler komposit. Pada fase awal rangkaian penelitian, pembuatan komposit dilakukan dengan metode yang relatif ekonomis yaitu hand lay-up. Sifatsifat mekanik dan daya serap air juga akan diuji sebagai langkah awal untuk menilai kualitas dari bahan komposit.

\section{BAHAN DAN METODE}

Penelitian ini menggunakan resin poliester merek Yucalac BQTN-157 merupakan tipe resin yang cepat kering, cocok digunakan pada pengaplikasian produk komposit dengan menggunakan metode hand lay-up dan sprayup molding. Resin poliester banyak di gunakan banyak digunakan pada pengaplikasian komposit di dunia industri dengan pertimbangan harga relatif murah, waktu curing cepat, warna jernih, dimensi yang stabil dan mudah penanganannya [5]. Bahan tambahan pendukung resin pada matriks komposit adalah penambahan katalis. Bahan kimia penambah pada matriks ini berfungsi dalam proses pembekuan atau pengeringan resin, penambahan katalis dalam jumlah banyak akan menimbulkan panas yang berlebihan pada saat proses curing [6]. Bahan katalis yang digunakan pada penelitian ini sebagai bahan penambah resin poliester dalam mempercepat proses pengeringan adalah methylethyl-ketone-peroxide (MEKP). Kecepatan resin menuju fase pada saat pengeringan atau pembekuan dapat dikontrol dengan penambahan katalis sebesar $0.5 \%-3 \%$ dari jumlah fraksi volume matriks. Penambahan katalis yang tidak tepat akan mempengaruhi proses curring. Matriks merupakan unsur yang bertugas untuk mengikat dan melindungi penguat [7]. Filler atau bahan pengisi yang digunakan dalam proses pembuatan komposit pada penelitian ini menggunakan cangkang dari biji karet yang telah dikumpulkan terlebih dahulu melalui petani karet.

Cangkang biji karet kemudian dibersihkan untuk menghilangkan pengotor yang melekat pada permukaan biji karet. Proses penghancuran awal dilakukan untuk mendapatkan ukuran pecahan cangkang maksimum $5 \mathrm{~mm}$. Proses penghancuran ini dilakukan dengan menggunakan mesin mini grinder yang relatif mudah untuk diperoleh. Proses ini diikuti dengan perendaman dan pengeringan masing-masing selama 6 jam. Gambar 1a menunjukkan kondisi cangkang biji karet setelah proses pembersihan awal. Biji karet berbentuk bola cenderung oval memiliki warna kecoklatan dengan ukuran $2-3 \mathrm{~cm}$. Tebal cangkang adalah $2 \mathrm{~mm}$. 
Cangkang tersebut memiliki karakteristrik yang keras dengan permukaan yang lembut. Gambar 1b menunjukkan ilustrasi cetakan yang digunakan dalam proses hand lay-up komposit. Cetakan terbuat dari kaca dengan ukuran $200 \mathrm{~mm}$ x $150 \mathrm{~mm}$. Ketebalan cetakan disesuaikan dengan standar uji tarik dan uji tekuk. Ukuran cetakan tersebut dibuat sedemikian rupa agar memungkinkan memotong spesimen sesuai dengan standar pengujian yang digunakan yaitu ASTM D638 [8] untuk uji tarik dan ASTM D790 [9] untuk uji tekuk. Permukaan cetakan dioleskan dengan release agent untuk mempermudah proses pelepasan komposit sehingga cetakan dapat digunakan kembali.
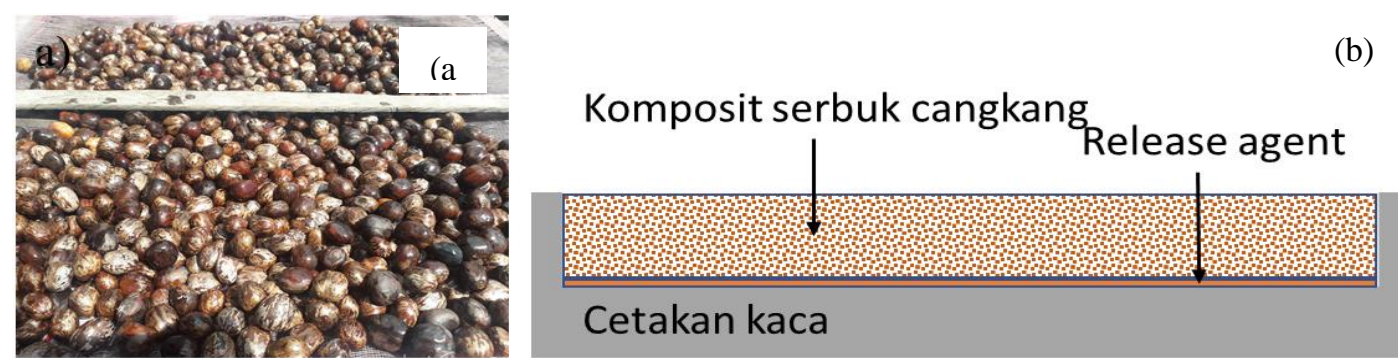

Gambar 1: a) Cangkang biji karet dalam kondisi, b) Ilustrasi cetakan kaca. Ketebalan cetakan disesuaikan dengan ketebalan standar spesimen ASTM yaitu D638 dan D790.

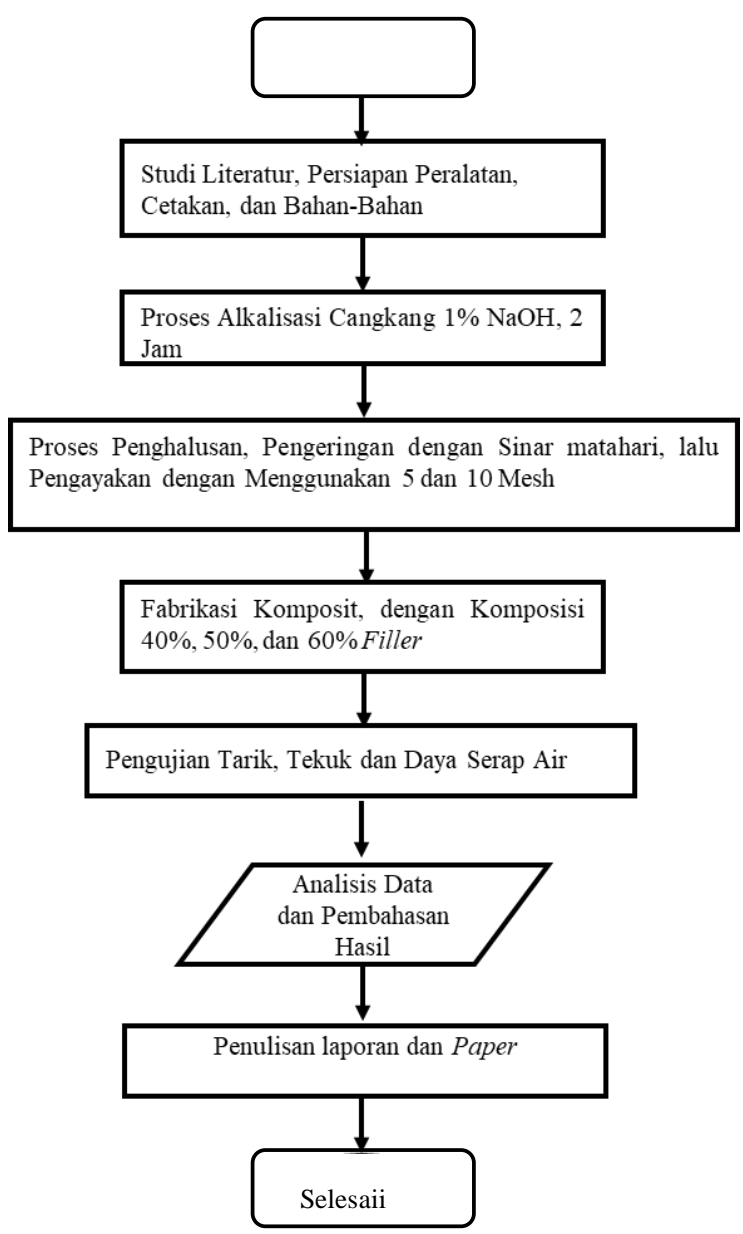

Gambar 2: Diagram proses penelitian yang menunjukkan garis-garis besar proses investigasi komposit serbuk cangkang biji karet.

Cangkang biji karet yang bersih dan kering tersebut kemudian mengalami proses alkalisasi dengan menggunakan larutan natrium hidroksida $(\mathrm{NaOH})$ 1\% dengan tambahan air distilasi. Proses selanjutanya adalah penghalusan menggunakan mini grinder dan pengayakan menggunakan ukuran 5 dan 10 mesh hingga didapatkan bahan filler serbuk. Proses pembuatan komposit dilakukan menggunakan metode hand lay-up 
dengan cetakan berbahan kaca. Untuk mempermudah pelepasan komposit dari cetakan maka digunakan mirror glaze. Hand lay-up merupakan salah satu teknik pembuatan komposit yang relatif mudah, cepat, dan ekonomis. Papan komposit kemudian dipotong untuk membentuk spesimen uji tarik dan uji teknik sesuai dengan standar yang ada. Uji tarik dilakukan pada mesin Tensilon RTD-2410 dengan menggunakan dimensi spesimen berdasarkan standar ASTM D638 [8]. Uji tekuk juga dilakukan pada mesin yang sama dengan menggunakan metode tiga titik yang diaplikasikan pada spesimen berdasarkan standar D790 [9]. Uji daya serap air dilaksanakan dengan melakukan perendaman 24 jam sesuai dengan prosedur yang pada standar ASTM D570 [10]. Secara umum proses penelitian tersebut di atas, dapat dilihat dalam diagram proses yang ditunjukkan pada Gambar 2.

\section{HASIL DAN DISKUSI}

\subsection{Kekuatan tarik}

Gambar 3 memperlihatkan kondisi cangkang biji karet yang telah mengalami proses penghalusan Gambar 3a serta hasil pembuatan papan komposit menggunakan cetakan kaca seperti pada gambar 3b. Papan komposit, gambar 3c, kemudian dipotong sesuai dengan dimensi standar pengujian tarik dan tekuk yang telah disebutkan pada sub bagian bahan dan metode.
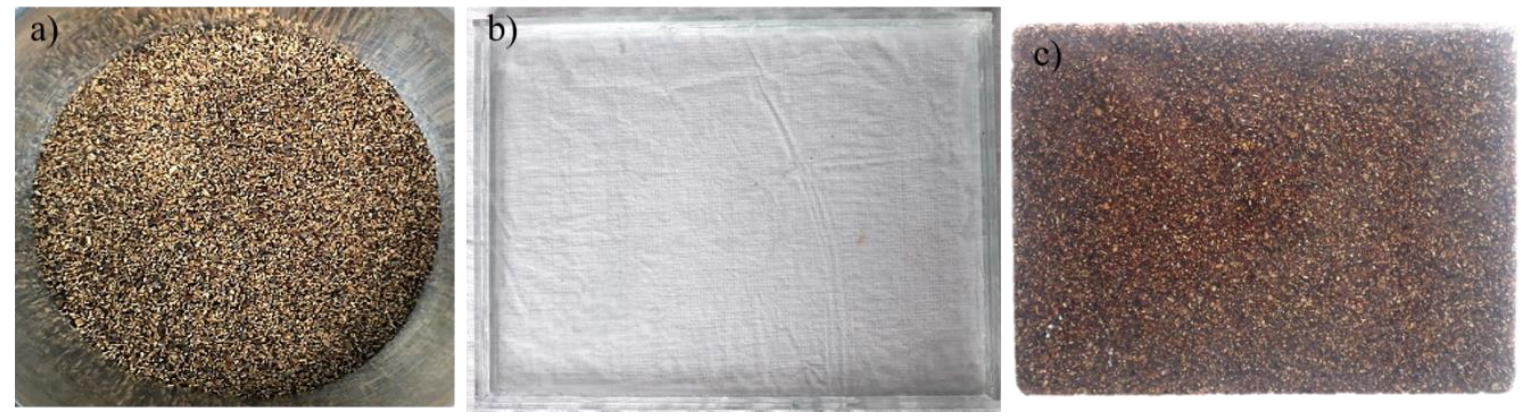

Gambar 3: Proses pembuatan komposit: a) Penghalusan cangkang dengan beberapa mesh, b) cetakan kaca ukuran 200 x $150 \mathrm{~mm}$ c) Papan komposit setelah dikeluarkan dari cetakan.

Gambar 4 menunjukkan grafik hasil uji tarik dari komposit serat alam berbasis cangkang biji karet. Pada gambar tersebut terlihat grafik evolusi tegangan - regangan komposit cangkang biji karet pada saat pembebanan. Beban dan perubahan panjang dari spesimen direkam menggunakan mesin UTM Tensilon RTF 2410, kecepatan tes adalah $10 \mathrm{~mm} / \mathrm{min}$. Hasil tes menunjukkan terjadinya penurunan kekuatan tarik seiring dengan penambahan fraksi volume serbuk. Dari grafik tegangan regangan dapat juga dilihat terjadinya non linearitas tegangan regangan pada fase awal setelah mengalami peningkatan secara linier. Fluktuasi tersebut juga ditemukan pada serat pisang [11] dan komposit serat karbon [12]. Fenomena ini kemungkinan akan ditemukan pada komposit serat alam yang memiliki ukuran serat pendek atau cenderung berbentuk serbuk yang mengakibatkan interaksi antara serbuk dan resin yang heterogen.

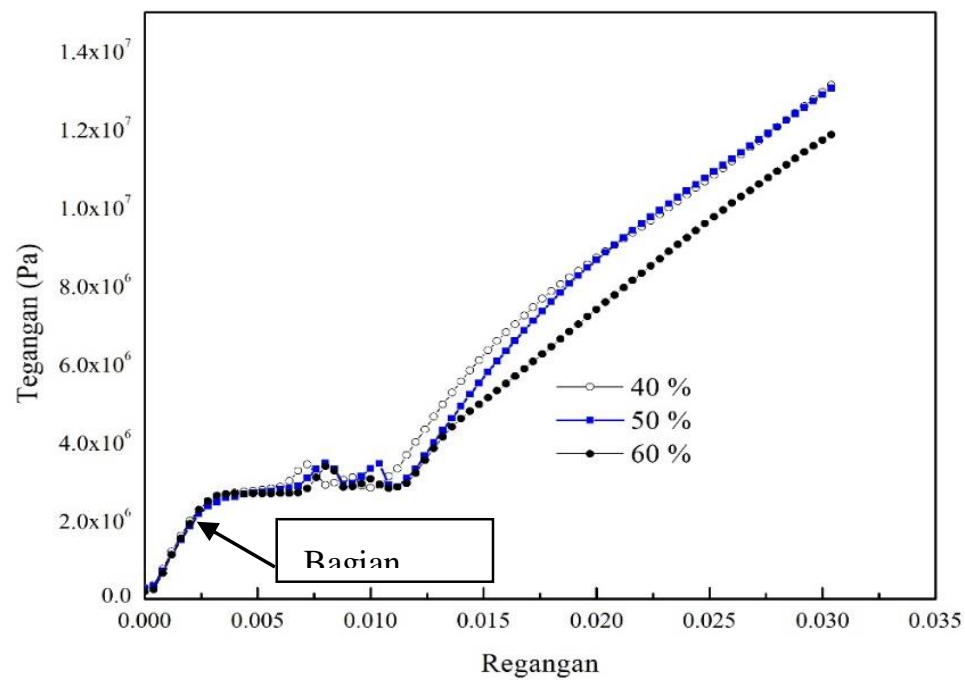

Gambar 4: Grafik tegangan regangan komposit cangkang biji karet. 
Grafik menunjukkan bahwa kekuatan tarik menurun dari $12.156 \pm 1.07 \mathrm{MPa}$ pada fraksi filler $40 \%$ menjadi $8.05 \pm 1.211 \mathrm{Mpa}$ untuk fraksi $60 \%$. Kecenderungan penurunan kekuatan tarik untuk komposit jenis serbuk juga telah dilaporkan oleh Susilowati [13]. Meskipun volume fraksi serbuk bertambah namun hal ini tidak efektif meningkatkan kekuatan karena ukuran serbuk yang kecil. Serbuk ukuran kecil juga tidak efektif menjadi penghalang perambatan retak karena ikatan yang terjadi antara matriks dan serbuk tidak efektif. Hal ini dapat dibuktikan dengan pola patahan lurus yang terjadi setelah uji tarik. Modulus elastisitas ditentukan dari bagian elastis atau linier dari grafik pada gambar 4 dengan memanfaatkan rasio antara tegangan-regangan. Bagian linier tersebut berada di antara rentang regangan 0 sampai dengan maksimum regangan 0.0028 pada gambar 4. Dari grafik tersebut nilai modulus elastisitas dari komposit berturut-turut adalah $1.01 \mathrm{Gpa}, 1.04 \mathrm{GPa}$ dan $1.08 \mathrm{GPa}$ untuk fraksi $40 \%, 50 \%$, dan $60 \%$. Dari nilai tersebut terlihat bahwa penambahan serbuk tidak berpengaruh besar pada elastisitas dari komposit. Hal ini dapat disebabkan oleh ukuran serbuk cangkang yang relatif hampir sama karena berasal dari ayakan dengan ukuran mesh sama. Gambar 5 menunjukkan pola patahan uji tarik komposit serbuk cangkang karet. Penambahan fraksi serbuk, pada dasarnya diharapkan dapat meningkatkan kekuatan tarik material, namun demikian hal tersebut tidak ditemukan pada investigasi ini. Selain ukuran serbuk, orientasi serbuk juga dapat memberikan pengaruh karena semakin besar fraksi serbuk maka semakin banyak area yang tidak searah dengan tegangan aksial atau arah tegangan tarik, hal ini menyebabkan tegangan geser bekerja lebih dominan pada saat material mendapat beban eksternal. Kecenderungan pengurangan kekuatan tarik ini juga telah dilaporkan oleh Olaitan [14] yang menemukan penurunan kekuatan pada serat alam cangkang kacang tanah dan cangkang padi. Jika dibandingkan dengan kedua hasil tersebut maka kekuatan yang dimiliki oleh komposit cangkang karet lebih kecil dari cangkang kacang tanah dan padi.

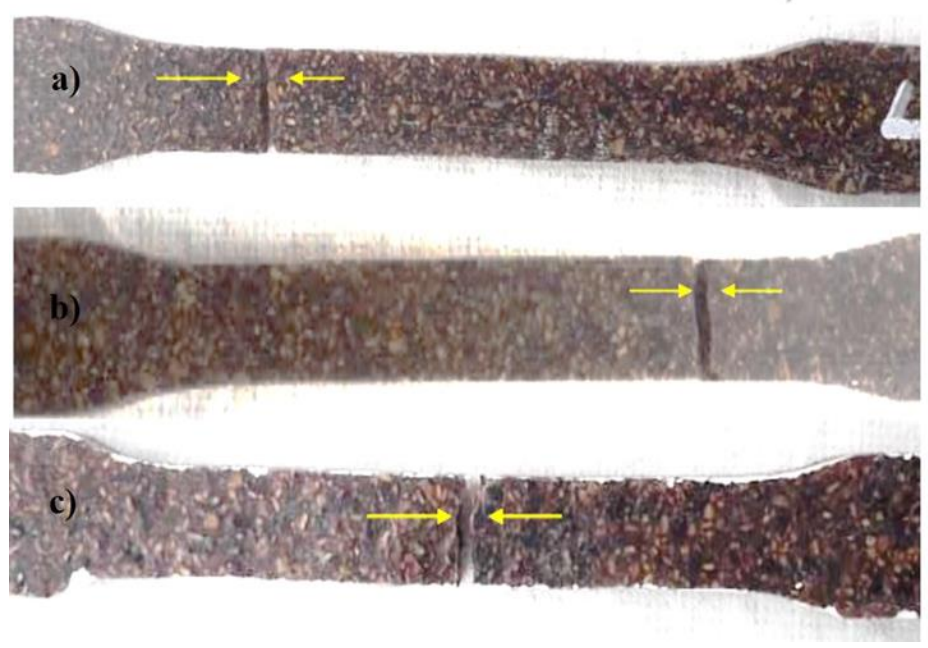

Gambar 5: Patahan hasil uji tarik: a) filler 40\%, b) 50\%, c) $60 \%$.

Jenis resin juga memiliki pengaruh besar dalam menentukan kekuatan tarik komposit alam $[15,16,17]$ selain pengaruh orientasi, dan ukuran pengisi. Hasil penelitian [18] lain yang memperlihatkan turunnya kekuatan apabila komposisi filler melebihi $60 \%$. Meskipun kekuatan tarik komposit serbuk biji karet lebih rendah dari beberapa jenis komposit dengan bentuk serat yang lebih panjang. komposit cangkang biji karet memiliki kesamaan dengan cangkang asam jawa baik itu pada ketebalan cangkang, dan modulus elastisitas komposit [19]. Dari gambar tersebut dapat dilihat pola patahan kontinyu menunjukkan sifat material getas yang terjadi pada ketiga jenis spesimen.

\subsection{Kekuatan tekuk}

Uji tekuk juga dilakukan pada mesin UTM Tensilon RTF 2410 dengan metode 3 titik. Hasil pengujian dan analisis memperlihatkan adanya penurunan kekuatan tekuk (flexural strength) apabila komposisi cangkang biji karet ditingkatkan. Penurunan kekuatan terjadi dari 76.52 MPa untuk komposisi 40\% menjadi 38.36 MPa dan 31.32 berturut-turut untuk komposisi 50\% dan 60\% seperti yang ditunjukkan pada Gambar 6. Hasil ini berbeda dengan hipotesis awal dan juga kecenderungan yang terjadi pada komposit serat alam lainnya, dimana penambahan fraksi akan meningkatkan kekuatan tekuk. Hal ini dapat dimengerti, bahwa terdapat kemungkinan komposit dengan jenis serbuk memiliki komposisi maksimum, apabila melebihi komposisi tersebut maka sifat- 
sifat mekaniknya cenderung menurun [20,21]. Lebih jauh lagi, penyebab turunnya kekuatan tekuk dapat dipengaruhi oleh bentuk serbuk (pecahan cangkang) yang tidak homogen dan arah cangkang yang relatif acak sehingga memungkinkan terjadinya gangguan pada ikatan antara matriks dan serbuk cangkang pengisi. Selain itu, jika ditinjau dari sudut pandang komposit berpenguat serat, kekuatan

mekanik dari komposit juga sangat tergantung dari panjang serat [22] karena akan mempengaruhi penyebaran serat di dalam matriks. Ukuran serat yang semakin kecil cenderung mengalami aglomerasi dan tidak tersebar merata di dalam matriks. Meskipun demikian, jika dibandingkan dengan komposit serat alam lainnya. Dalam penelitian ini, komposit cangkang biji karet memiliki kekuatan tekuk yang relatif tinggi pada komposisi $40 \%$ [22]. Namun, hal ini perlu investigasi lanjutan dengan berbagai variasi baik bentuk, ukuran, metode pembuatan komposit, dan jenis resin.

\section{Kekuatan Tekuk}

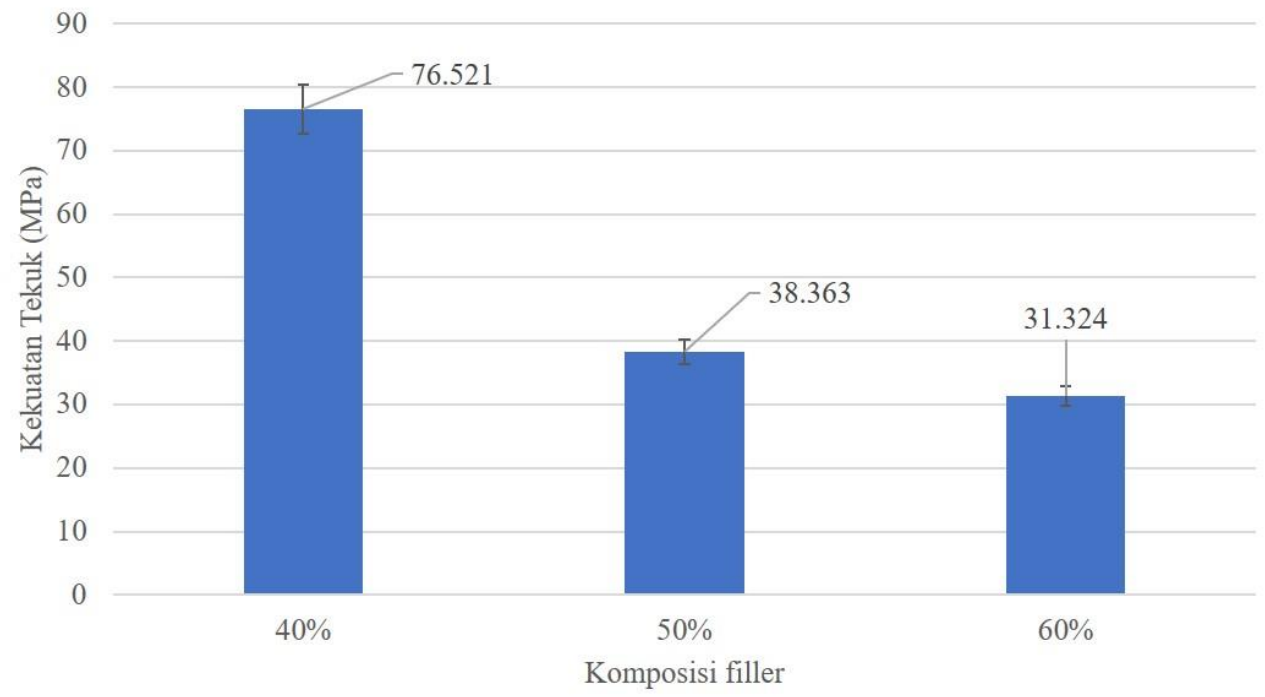

Gambar 6: Kekuatan tekuk komposit.
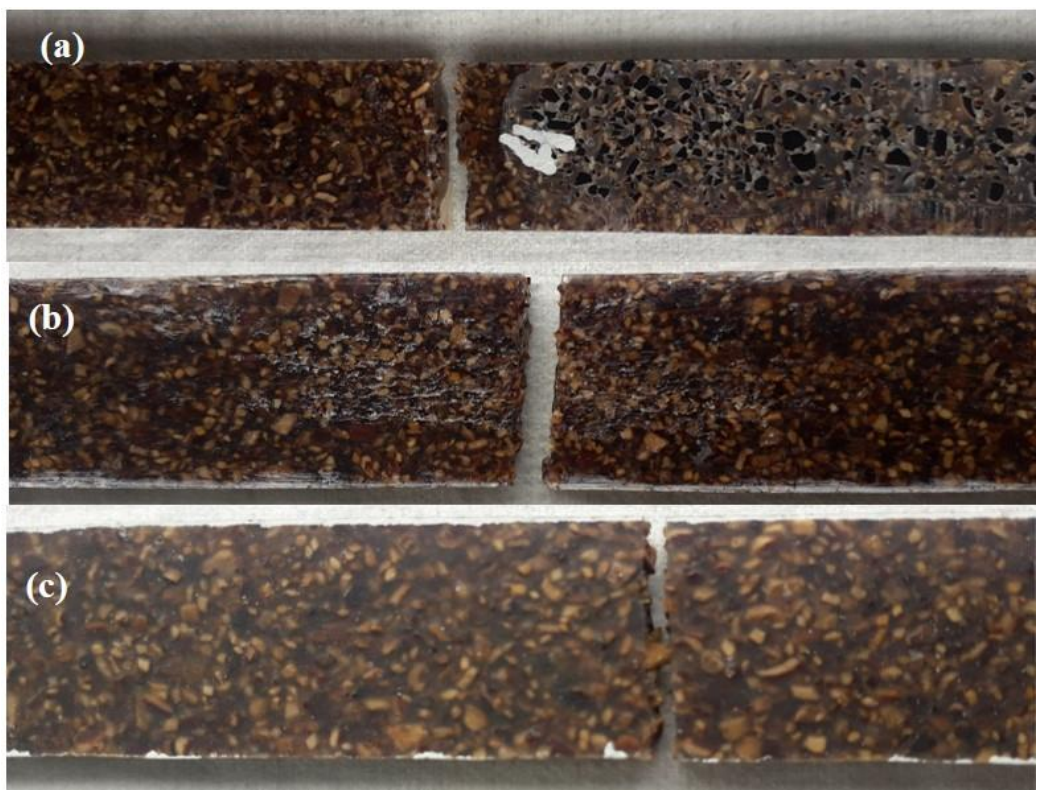

Gambar 7: Patahan hasil uji tekuk: a) filler $40 \%$, b) $50 \%$, c) $60 \%$.

Gambar 7 memperlihatkan patahan spesimen setelás pengujian tekuk. Gambar tersebut menunjukkan pola patahan lurus yang identik dengan patahan pada uji tarik. Gambar patahan (a), (b), dan (c) menegaskan ikatan yang tidak efektif antara matriks dan serbuk pengisi. Pada gambar 7(c), dengan tanda panah putih, juga terlihat serbuk atau terpisah dari matriks tanpa munculnya tanda retak atau patah pada serbuk tersebut. Pada 
gambar 7(a), (b), dan (c) juga terlihat susunan serbuk-serbuk yang mengisi matriks secara acak. Ukuran dan morfologi serbuk tersebut juga bervariasi sehingga kemungkinan dapat mempengaruhi sifat-sifat mekanik dari komposit tersebut. Penambahan komposisi serbuk pengisi akan meningkatkan kemungkinan antar muka serbuk saling berdekatan dan mengurangi daya ikat resin.

\subsection{Pengujian daya serap air (DSA)}

Gambar 8 memperlihatkan hasil DSA komposit serbuk cangkang biji karet. Gambar tersebut mengungkapkan terjadinya peningkatan DSA setelah perendaman selama 24 jam.

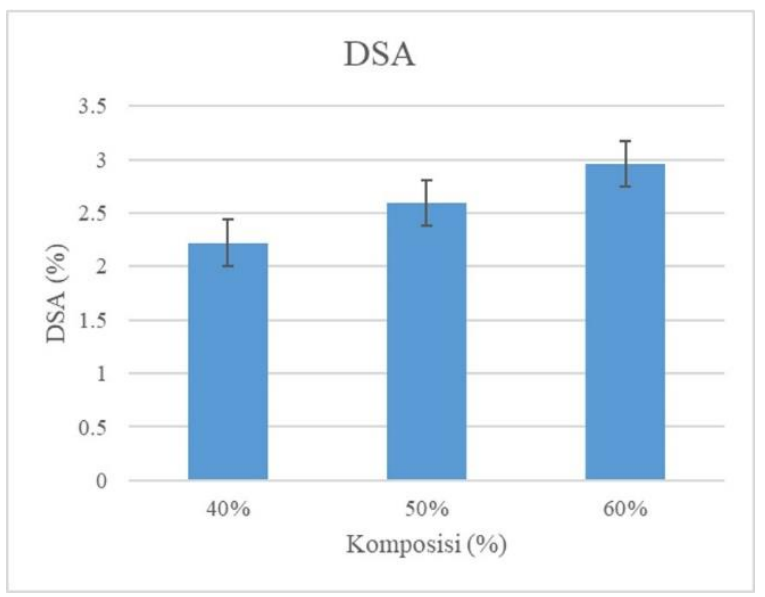

Gambar 8: Daya serap air komposit cangkang biji karet.

Peningkatan ini disebabkan oleh bertambahnya volume serbuk pengisi seperti yang telah ditemukan pada penelitian yang lain [23]. Meskipun terjadi peningkatan DSA sebesar hampir 3\% pada komposit dengan pengisi $60 \%$, angka tersebut masih jauh di bawah persyaratan maksimum berdasarkan standard nasional indonesia (SNI), sehingga komposit cangkang biji karet memiliki potensi untuk aplikasi interior. Berdasarkan SNI mengenai mutu papan partikel (komposit), persentase kadar air yang diperkenankan tidak lebih dari $14 \%$ sehingga memperkuat potensi cangkang biji karet sebagai material pengisi. Dari gambar di atas dapat diketahui bahwa DSA dipengaruhi oleh komposisi serbuk pengisi, selain itu beberapa jenis matriks memiliki sifat yang tahan terhadap air sehingga pemilihan jenis matriks juga akan mempengaruhi daya serap air sebuah komposit. Detail mengenai jenis-jenis matriks dan hubungannya terhadap daya serap air dapat dilihat melalui pustaka [24]. Selain dua faktor di atas, untuk komposit jenis serbuk yang memiliki sebaran, posisi, dan orientasi acak, permukaan juga memiliki pengaruh yang besar dalam DSA. Serbuk yang berada pada permukaan akan menjadi sumber penyerapan air. Meskipun demikian, karaktersitik DSA dapat ditingkatkan melaui proses alkalisasi dengan konsetrasi $\mathrm{NaOH}$ yang lebih tinggi [25] sehingga ruang aplikasi untuk komposit menjadi semakin lebar.

\section{KESIMPULAN}

1. Komposit berbahan pengisi serbuk cangkang biji karet dengan variasi komposisi serbuk pengisi telah berhasil dibuat.

2. Pengujian pada penelitian ini, kekuatan tarik tertinggi pada komposit dengan komposisi pengisi $40 \%$ dengan kekuatan tarik 12.156 $\pm 1.07 \mathrm{MPa}$. Penambahan komposisi akan mengakibatkan terjadinya penurunan kekuatan yang signifikan akibat geometri serbuk pengisi.

3. Nilai kekuatan tekuk juga mengalami penurunan pada komposisi serbuk $50 \%$ dan $60 \%$ dengan nilai masing-masing 38.36 MPa dan 31.32 MPa. Nilai tersebut turun 50\% dari 76.52 MPa pada komposisi 40\% sehingga penambahan serbuk pengisi berakibat detrimental pada kekuatan tekuk komposit ini.

4. Pengujian DSA menunjukkan hasil yang cukup baik dimana didapatkan rata-rata persentase daya serap air pada variasi massa filler 40\%, 50\%, dan 60\% yaitu sebesar 2.22\%, 2.59\%, dan 2.96\%. Hasil ini menunjukkan potensi yang cukup bagi komposit serbuk cangkang biji karet untuk aplikasi terbatas pada furnitur atau interior.

\section{DAFTAR PUSTAKA}

[1] KEMENTERIAN PERTANIAN. 2020. Data Luas Lahan Pertanian 2019. Jakarta. 
[2] BANON CHARLES, SUTANTO T.D, GUSTIAN IRFAN, KOHARUDIN ILMAN, RAHMI WIDIA. "Cangkang buah karet dengan perekat limbah plastik polipropilena sebagai alternatif papan partikel". Jurnal Kimia Riset, vol. 01, no. 2, pp. 86-93, 2016.

[3] VAN VLACK, L.H. Ilmu Teknologi Bahan. Terjemahan DR. Ir. Sriati Djaprie. Edisi kelima, penerbit: Erlangga, Jakarta. 1991.

[4] PRADANA M. ADITYA, ARDHYANANTA HOSTA, FARID M. "Pemisahan selulosa dari lignin serat tandan kosong kelapa sawit dengan proses alkalisasi untuk penguat bahan komposit penyerap suara". Jurnal Teknik ITS, vol.6, no.02, ISSN: 2337-3539. 2017.

[5] CHANDRAMOHAN. D, JOHN PRESIN KHUMAR. A. "Experimental data on the properties of natural fiber particle reinforced polymer composite material". Data in Brief, 460-468. 2017.

[6] BILMEYER JR, F.W. “Textbook of Polymer Science”, 3rd Ed., John Wiley \& sons, Inc. 1984.

[7] DAVALLO, M., PASDAR, H., MOHSENI, M. Mechanical Properties of Unsaturated Poliester Resin, Internasional Journal of ChemTech Research, Vol. 2, No. 4, pp. 2113-2117. 2010.

[8] ASTM D-638. "Standart Test Method for Tensile Properties of plastics". Philadelphia, PA: American Society For Testing Material. 2014.

[9] ASTM D570-98. "Standard Test Method for Water Absorption of Plastic". American Cociety for testing and Materials, Philadelpia. 2010.

[10] ASTM D790. "Standard Test Method for Flexural Properties Unrenforced and Reinforced Plastic and Electrical Insulating Materials". American Cociety for testing and Materials, Philadelpia. 2001.

[11] V.K. SINGH, P.C. GOPE, C. SAKSHI, B.D. SINGH. "Mechanical behavior of banana fiber based hybrid bio composites". J. Mater. Environ. Sci., 185-194. 32012.

[12] G.T. TRUONG, H. VAN TRAN, K.K. CHOI. "Tensile Behavior of Carbon Fiber-Reinforced Polymer Composites Incorporating Nanomaterials after Exposure to Elevated Temperature". J. Nanomater. 2019.

[13] SUSILOWATI SRIENDAH. "Studi Perlakuan Alkali Terhadap Sifat Mekanik Bahan Komposit Berpenguat Sekam Padi”. Tesis. Fakultas Teknik. Universitas 17 Agustus 1945 Jakarta. 2017.

[14] A. OlaitAN, A. TERHEMEN, G. KING, O. OLUWATOYIN. "Comparative Assessment of Mechanical Properties of Groundnut Shell and Rice Husk Reinforced Epoxy Composites”, Am. J. Mech. Eng. Vol. 5, pp. 76-86. 2017.

[15] N. IZZATI ZULKIFLI, N. SAMAT, H. ANUAR, N. ZAINUDDIN. "Mechanical properties and failure modes of recycled polypropylene/microcrystalline cellulose composites", Mater. Vol. 69, pp. 114-123. 2015.

[16] M. CORDIN, T. BECHTOLD, T. PHAM. "Effect of fibre orientation on the mechanical properties of polypropylene-lyocell composites". Cellulose. Vol. 25, pp. 7197-7210. 2018.

[17] A. FADHILLAH, S. SETIYABUDI, A. PURNOWIDODO. "Karakteristik Komposit Serat Kulit Pohon Waru (Hibiscus Tiliaceus) Berdasarkan Jenis Resin Sintetis terhadap Kekuatan Tarik dan Patahan Komposit”. Jurnal Rekayasa Mesin. Vol. 8, pp. 101-108. 2017.

[18] L. NURIYAH. "Pengaruh Komposisi Filler Terhadap Kekuatan Tarik Dan Ketangguhan Bahan Komposit Serbuk Sekam Padi" Resin. pp. 2-3. 2012.

[19] M.H.M. AMIN, A.M.T. ARIFIN, M.F. HASSAN, R.H.A. HAQ, M.N.A. RAHMAN, A.E. ISMAIL, M.Z. RAHIM, M.R. IBRAHIM, M.Z. YUNOS, R. ISMAIL. "An Evaluation of Mechanical Properties on Kenaf Natural Fiber/Polyester Composite Structures as Table Tennis Blade”. J. Phys. Conf. Ser. Vol. 914. 2017.

[20] S. GOUDAR, R.K. JAIN, D. DAS. "Physico-mechanical properties of tamarind pod shell-based composite". Polym. Compos. Vol. 41, pp. 505-521. 2020.

[21] S.R. SACHIN, T.K. KANNAN, R. RAJASEKAR. "Effect of wood particulate size on the mechanical properties of PLA biocomposite". Pigment Resin Technol. Vol. 49, pp. 465-472. 2020.

[22] S. JOSEPH, M.S. SREEKALA, Z. OOMMEN, P. KOSHY, S. THOMAS. "A comparison of the mechanical properties of phenol formaldehyde composites reinforced with banana fibres and glass fibres". Compos. Sci. Technol. Vol. 62, pp. 1857-1868. 2002.

[23] A. SINGH, "Study of Mechanical Properties and Absorption Behaviour of Coconut Shell Powder-Epoxy Composites". Int. J. Mater. Sci. Appl. Vol. 2, pp. 157. 2013.

[24] A.A. KLYOSOV. "Wood-Plastic Composites". 2007.

[25] N. NANULAITTA, W. SOEPRAPTO, R. SOENOKO. "Pengaruh Fraksi Volume Serat Empulur Sagu (Metroxylon sp) dan Presentase Alkali terhadap Pengujian Impak serta Absorpsi Air pada Komposit Berserat Sagu”. Jurnal Rekayasa Mesin. Vol. 9, pp. 163-168. 2018. 